\title{
HUBUNGAN KADAR D-DIMER DENGAN AWITAN GEJALA DAN LAMA PERAWATAN PADA PENDERITA CEREBRAL VENOUS SINUS THROMBOSIS DI RSUP DR HASAN SADIKIN BANDUNG
}

\author{
CORRELATION BETWEEN D-DIMER LEVEL WITH ONSET OF SYMPTOMS AND LENGTH OF \\ STAY IN CEREBRAL VENOUS SINUS THROMBOSIS PATIENTS AT HASAN SADIKIN HOSPITAL \\ $B A N D U N G$
}

Lisda Amalia, * Adnin Nugroho*

\begin{abstract}
Introduction: Cerebral venous sinus thrombosis (CVST) is one of a cerebrovascular disease with a diverse and elusive clinical presentation. Diagnosis is often challenging due to limitation in diagnostic tools. Coagulation disorder is one of the risk factor for CVST that can be seen from D-dimer level which tends to increase in CVST patients.

Aim: This study aims to determine the D-dimer level and its correlation with onset of symptoms and length of stay in CVST patients at Hasan Sadikin Hospital, Bandung.

Methods: This is a cross-sectional study. The inclusion criteria were patients at Hasan Sadikin Hospital, Bandung diagnosed as CVST, confirmed by digital subtraction angiography (DSA) or computed tomography angiography (CTA) or magnetic resonance angiography (MRA) and had blood coagulation profile in the period of January $2018-M a y 2019$. Exclusion criteria were patients with infection or sepsis. Data were collected from the patient's medical record. Statistical value was calculated with Spearman rank test, $p$ value $<0.05$ was considered significant.

Results: Forty CVST patients met the criteria. CVST mostly occurred in women (80\%), the mean age were 40,75 years, and had headache as primary symptom (70\%). Twenty-eight (70\%) patients had increased level of D-dimer. D-dimer level had negative correlation with onset of symptoms $(r=-0.319, p=0.045)$. However, it had association with length of stay $(p=0.012)$.
\end{abstract}

Discussion: D-dimer level in CVST patients tends to increase above normal value. D-dimer level have correlation with onset of symptoms and length of stay in CVST patients.

Keywords: Cerebral venous sinus thrombosis, D-dimer level, length of stay, onset of symptoms

\section{ABSTRAK}

Pendahuluan: Trombosis pada vena serebral ( CVST) merupakan salah satu diagnosis dalam bidang cerebrovaskular yang sulit ditegakkan karena keterbatasan alat untuk diagnosis pasti. Salah satu faktor risiko terjadinya CVST adalah kelainan koagulasi yang dapat dilihat dari kadar D-dimer yang cenderung meningkat.

Tujuan: Mengetahui gambaran profil D-dimer pada penderita CVST dan hubungannya dengan awitan gejala dan lama perawatan di RSUP Dr. Hasan Sadikin, Bandung.

Metode: Penelitian ini merupakan penelitian potong lintang. Kriteria inklusi yaitu pasien yang terdiagnosis CVST melalui pemeriksaan digital substraction angiography (DSA) atau computed tomography angiography (CTA) atau magnetic resonance angiography (MRA) dan memiliki profil koagulasi serta dirawat di RSUP Dr. Hasan Sadikin, Bandung pada periode Januari 2018-Mei 2019. Kriteria eksklusi yaitu pasien yang disertai infeksi atau sepsis. Data diambil dari penelusuran rekam medis pasien dan dianalisis menggunakan korelasi Spearman. Signifikansi dinyatakan bila $\mathrm{p}<0,05$.

Hasil: Terdapat 40 pasien CVST yang memenuhi kriteria inklusi. CVST mayoritas terjadi pada perempuan (80\%), rerata usia 40,75 tahun dengan keluhan utama tersering adalah nyeri kepala (70\%). Terdapat 28 pasien memiliki kadar D-dimer yang meningkat (70\%). Berdasarkan analisis, kadar D-dimer memiliki hubungan negatif dengan awitan gejala pasien $(r=0,319, p=0,045)$. Kadar D-dimer juga memiliki hubungan dengan lama perawatan $(\mathrm{p}=0,012)$

Diskusi: Kadar D-dimer pada penderita CVST cenderung lebih tinggi dari nilai normal. Kadar D-dimer memiliki hubungan dengan awitan gejala dan lama perawatan pasien CVST di rumah sakit.

Kata kunci: Awitan gejala, cerebral venous sinus thrombosis, kadar D-dimer, lama perawatan

*Departemen Neurologi FK Universitas Padjadjaran/RSUP Dr. Hasan Sadikin, Bandung, Indonesia. Korespondensi: dr.lisda@gmail.com.

\section{PENDAHULUAN}

Penyakit trombosis pada vena cerebral atau cerebral venous sinus trombosis (CVST) merupakan jenis stroke yang jarang terjadi. ${ }^{1} \mathrm{CVST}$ paling banyak ditemukan pada dewasa muda dengan insidensi menyerang 5 orang per 1.000 .000 penduduk setiap tahunnya dan merupakan penyumbang 0,5-1\% dari kasus stroke. ${ }^{2}$ Manifestasi klinis dari CVST bermacam- 
macam seperti nyeri kepala, paresis saraf kranialis, kejang, ataupun penurunan kesadaran. ${ }^{1}$

Pemeriksaan neuroimajing diperlukan untuk mendiagnosis suatu CVST. Pemeriksaan tersebut dapat dibedakan menjadi 2 yaitu metode non-invasif berupa computed tomography angiography (CTA) atau magnetic resonance angiography (MRA) serta metode invasif berupa digital subtraction angiography (DSA). ${ }^{1-}$ ${ }^{2}$ Akan tetapi, karena keterbatasan alat dan tidak semua fasilitas kesehatan memilikinya, diagnosis CVST juga dapat terlambat. ${ }^{5}$

Faktor risiko dari CVST dapat berupa infeksi, genetik, faktor hormonal, keganasan, dan gangguan koagulasi darah. ${ }^{1-2}$ Salah satu penanda gangguan koagulasi darah adalah kadar D-dimer plasma. Pemeriksaan ini cukup murah dan cukup mudah dikerjakan. Beberapa penelitian sebelumnya menyebutkan bahwa kadar D-dimer plasma berhubungan dengan diagnosis CVST. ${ }^{2-5}$ Rekomendasi dari American Heart Association (AHA) dan American Stroke Association (ASA) menyebutkan bahwa pasien dengan kadar D-dimer yang tinggi dapat mengindikasikan kemungkinan adanya CVST, dibandingkan dengan nilai D-dimer yang normal. Penelitian yang telah dilakukan di China didapatkan bahwa, pasien yang telah didiagnosis CVST dan memiliki kadar D-dimer yang tinggi memiliki kecenderungan lebih lamanya berkurang gejala dibandingkan dengan yang memiliki kadar D-dimer normal. Akan tetapi, tingkatan rekomendasi ini belum kuat (class IIb; level of evidence B). ${ }^{2}$

Penelitian ini bertujuan untuk mengetahui gambaran kadar D-dimer dan hubungannya dengan awitan gejala dan lama rawat pasien CVST di RSUP Dr. Hasan Sadikin, Bandung.

\section{METODE}

Penelitian ini merupakan penelitian potong lintang untuk melihat gambaran kadar D-dimer saat perawatan di RS pada penderita CVST dan menilai korelasinya dengan awitan keluhan dan lama rawat pasien. Sumber data yaitu data sekunder dari semua rekam medis pasien-pasien yang dirawat dengan CVST di ruang rawat inap neurologi RSUP Dr. Hasan Sadikin, Bandung selama bulan Januari 2018-
Mei 2019. Kriteria inklusi yaitu pasien-pasien yang didiagnosis CVST berdasarkan DSA atau CTA atau MRA. Selain itu pasien tersebut sudah diperiksa profil koagulasinya. Kriteria eksklusi pada penelitian ini yaitu pasien-pasien yang disertai dengan infeksi atau sepsis (Gambar 1).

Peneliti mengambil data karakteristik pasien berupa usia, jenis kelamin, keluhan utama, awitan keluhan, lokasi trombosis vena, kadar D-dimer, lama perawatan, serta pengobatan sebelumnya. Awitan keluhan dikelompokkan menjadi 3, yaitu akut (awitan $\leq 21$ hari), subakut (awitan 22-90 hari), dan kronis (awitan $>90$ hari). Kadar D-dimer dikelompokkan menjadi meningkat $(>0,55 \mathrm{mg} / \mathrm{dL})$ dan normal $(<0,55 \mathrm{mg} / \mathrm{dL})$. Lama perawatan dikelompokkan menjadi $\leq 7$ hari dan $>7$ hari. Pengelompokkan berdasarkan perjalanan penyakit CVST dari akut $(\leq 7$ hari) dan subakut ( $>7$ hari).

Analisis hubungan antara kadar D-dimer dengan awitan gejala menggunakan analisis non-parametrik korelasi Spearman. Analisis hubungan antara kadar D-dimer dengan lama perawatan menggunakan analisis tes Fisher's exact. Kedua analisis dilakukan dengan menggunakan program IBM SPSS Statistic 22.0.

Penelitian ini telah mendapatkan persetujuan etik dari Komite Etik Penelitian Kesehatan RSUP Dr. Hasan Sadikin, Bandung nomor LB.02.01/X.65/ 249/2019.

\section{HASIL}

Terdapat 40 pasien CVST yang memenuhi kriteria pada penelitian ini dengan karakteristik tercantum pada tabel 1.

Pada penelitian ini didapatkan bahwa $80 \%$ subjek berjenis kelamin perempuan. Hal ini sesuai dengan literatur bahwa sebagian besar kasus CVST terjadi pada perempuan. ${ }^{1,2-5}$ Subjek penelitian memiliki rentang usia dari 19-65 tahun. Sebanyak 87,5\% subjek penelitian ini terdiagnosis CVST melalui DSA dengan lokasi terbanyak ada di sinus transversus kiri. Hal ini bertentangan dengan rekomendasi dari AHA/ ASA bahwa pemeriksaan yang dianjurkan untuk diagnostik CVST dengan MRI dan MRV. ${ }^{2}$ Sebanyak 32 pasien $(70 \%)$ datang dengan keluhan utama 
Pasien dengan diagnosis CVST berdasarkan DSA/CTA/MRV yang dirawat di bangsal neurologi RSUP Dr. Hasan Sadikin Bandung

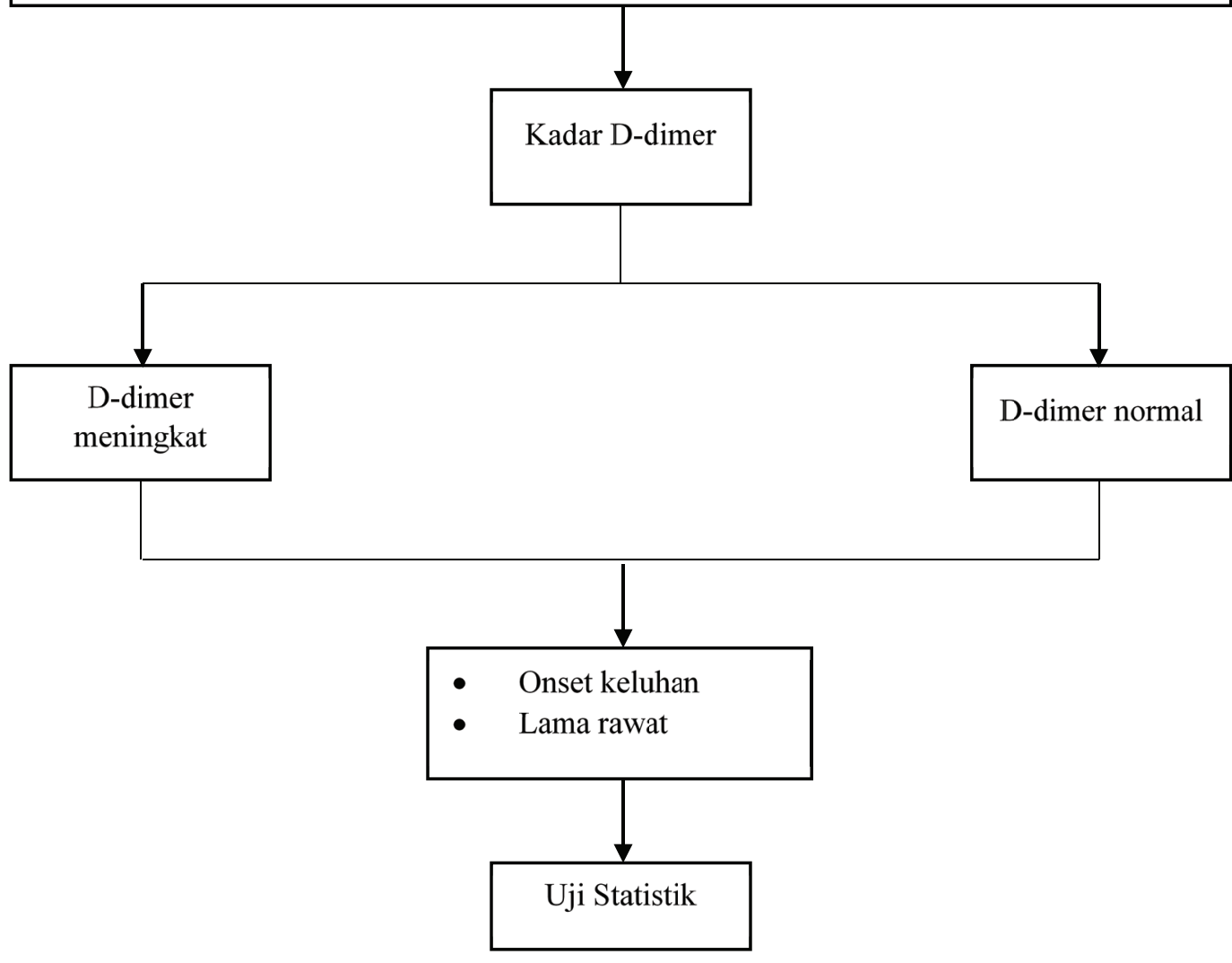

Gambar 1. Alur Penelitian

nyeri kepala dengan median awitan keluhan 60 hari (rentang 1-7300 hari).

Pada penelitian ini, 28 pasien $(70 \%)$ pasien CVST memiliki kadar D-dimer yang meningkat dengan rata-rata $0,9583 \mathrm{mg} / \mathrm{dL}$. Hal ini sesuai dengan penelitian sebelumnya yang menyebutkan bahwa pasien CVST cenderung memiliki kadar D-dimer yang meningkat $(>0,5 \mathrm{mg} / \mathrm{dL}) .^{3-4,7-8}$

\section{Hubungan antara Kadar D-dimer dengan Awitan Keluhan}

Pada penelitian ini didapatkan korelasi negatif yang signifikan antara kadar D-dimer dengan awitan gejala $(r=0,319, p=0,045)$. Semakin tinggi kadar $\mathrm{D}-$ dimer, maka semakin cepat awitan keluhan (Gambar 2).

\section{Hubungan antara Kadar D-dimer dengan Lama} Rawat

Pada penelitian ini didapatkan hubungan yang signifikan antara kadar D-dimer dengan lama perawatan di RS ( $\mathrm{p}=0,012)$.

\section{PEMBAHASAN}

Cerebral venous sinus thrombosis (CVST) atau trombosis sinus serebral merupakan penyakit akibat oklusi struktur vena intrakranial, termasuk sinus serebral, vena korteks, dan bagian proksimal vena jugularis. Hal ini menyebabkan berbagai manifestasi klinis akut dan kronik. Tanda dan gejala klinis CVST sangat bervariasi, dapat bersifat akut, subakut ataupun kronis. Tanda dan gejala klinis terutama adalah nyeri kepala, dapat disertai kejang, akan tetapi mungkin juga tidak spesifik sehingga dalam menegakkan diagnosis berdasarkan gambaran radiologis sedini mungkin sangat penting dan penatalaksanaan spesifik dapat diberikan secepat mungkin. ${ }^{2-6}$

Pada penelitian ini didapatkan 40 orang pasien yang didiagnosis CVST dan $80 \%$ diantaranya berjenis kelamin perempuan. Penelitian-penelitian sebelumnya mengenai CVST juga menunjukkan hasil yang sama. ${ }^{3-4,6-9}$ Hal ini dikarenakan kondisi perempuan yang berkaitan dengan penggunaan 


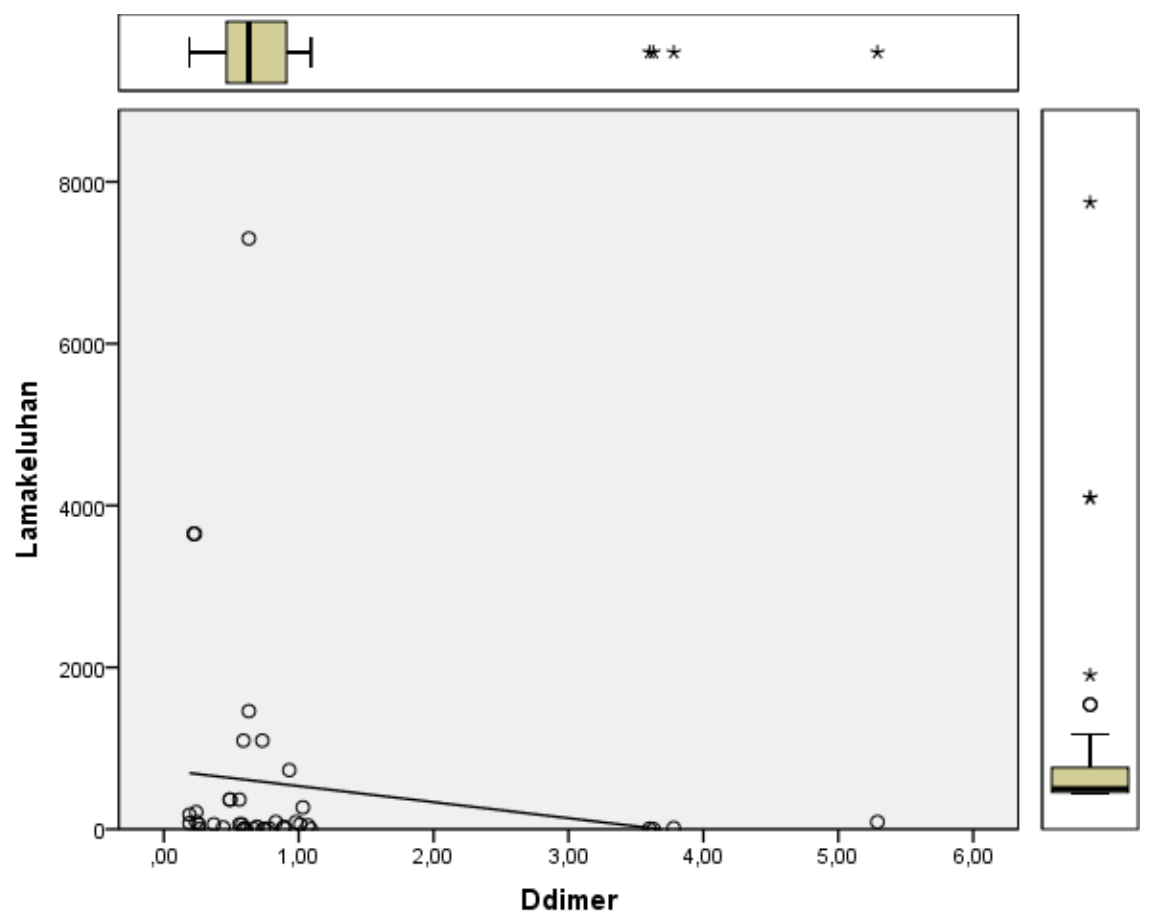

Gambar 2. Diagram Tebar Kadar D-dimer dengan Awitan Keluhan

Hal ini terbukti pada penelitian ini bahwa semua pasien yang sudah mendapat terapi antikoagulan atau antiplatelet sebelumnya memiliki kadar D-dimer yang normal.

Pada penelitian ini didapatkan korelasi negatif yang signifikan antara kadar D-dimer dengan awitan gejala $(r=-0,319, p=0,045)$. Semakin tinggi kadar D-dimer, maka semakin cepat awitan keluhan. Hal ini sesuai dengan penelitian yang dilakukan oleh Kosinski yang menyebutkan bahwa kadar D-dimer berkorelasi negatif dengan awitan gejala pada pasien $(\mathrm{r}=-0,58, \mathrm{p}<0,001) .{ }^{8}$ Hal ini kemungkinan karena kadar D-dimer yang tinggi berkaitan dengan kondisi hiperkoagulasi darah yang lebih besar sehingga memungkinkan terjadinya trombus yang lebih besar di pembuluh darah., ${ }^{4,15} \mathrm{Hal}$ ini dapat menyebabkan gejala yang lebih hebat sehingga pasien cenderung

Tabel 2. Tabulasi Silang antara Kadar D-dimer dengan Lama Rawat $(n=40)$

\begin{tabular}{lcccc}
\hline \multirow{2}{*}{ D-dimer Kadar } & \multicolumn{4}{c}{ Lama Rawat } \\
\cline { 2 - 5 } & $\leq$ H Hari & $>$ 7 Hari & Total & $\mathbf{p}^{*}$ \\
\hline Normal & 11 & 1 & 12 & \\
Tinggi & 13 & 15 & 28 & 0,012 \\
Total & 24 & 16 & 40 & \\
*Uji Pearson. & & &
\end{tabular}

datang lebih cepat ke RS untuk mendapatkan terapi. Selain itu, kadar D-dimer juga cenderung menurun seiring bertambahnya waktu, sehingga pasien-pasien dengan awitan gejala yang lebih lama cenderung memiliki kadar D-dimer normal atau rendah. ${ }^{2}$ Seperti telah disebutkan sebelumnya bahwa kadar D-dimer berhubungan dengan besarnya trombus di pembuluh darah. ${ }^{2,4,8,15}$ Hal ini dapat menyebabkan manifestasi gejala yang muncul pada pasien akan lebih berat dibandingkan pasien dengan kadar D-dimer normal. Pasien dengan gejala yang lebih berat memerlukan waktu perawatan yang lebih lama di RS sebelum dapat menjalani rawat jalan.

Pada penelitian ini didapatkan hubungan yang signifikan antara kadar D-dimer dengan lama perawatan di RS (Tabel 2). Seperti telah disebutkan sebelumnya bahwa kadar D-dimer berhubungan dengan besarnya trombus di pembuluh darah., ${ }^{2,4,8,15}$ Hal ini dapat menyebabkan manifestasi gejala yang muncul pada pasien akan lebih berat dibandingkan pasien dengan kadar D-dimer normal. Pasien dengan gejala yang lebih berat memerlukan waktu perawatan yang lebih lama di RS sebelum dapat menjalani rawat jalan. Belum ada penelitian tentang CVST yang mengevaluasi kadar D-dimer dengan 
lama perawatan dan penelitian ini merupakan yang pertama kali menilai hal ini. Salah satu faktor yang dapat menyebabkan lama perawatan adalah keluhan yang masih ada pada pasien.

Keterbatasan penelitian ini adalah penelitian potong lintang, serta tidak menganalisis pengobatan yang didapat pasien sehingga tidak bisa mendapatkan data yang lengkap dan faktor bias yang tinggi sehingga diperlukan penelitian yang bersifat prospektif. Selain itu pula pada penelitian ini tidak memberikan gambaran mengenai faktor risiko pada pasien-pasien CVST di RSUP Dr. Hasan Sadikin, Bandung. Jumlah subjek penelitian yang sedikit mengakibatkan jumlah subjek pada kelompok D-dimer tinggi dan normal tidak seimbang, sehingga penilaian untuk rasio Odds (RO) tidak bisa dinilai.

\section{KESIMPULAN}

Berdasarkan penelitian ini dapat disimpulkan bahwa pasien CVST di RSUP Dr. Hasan Sadikin, Bandung cenderung memiliki kadar D-dimer yang meningkat. Terdapat hubungan yang signifikan antara kadar D-dimer dengan awitan gejala dan lama perawatan di RS.

\section{DAFTAR PUSTAKA}

1. Caplan LR. Caplan's stroke: a clinical approach. Edisi ke-4. Philadelphia: Saunders Elsevier; 2009. h. 122-8.

2. Saposnik G, Barinagarrementeria F, Brown RD. Diagnosis and management of cerebral venous thrombosis. Stroke. 2014;42(4):1158-92.

3. Dentali F, Squizzato A, Marchesi C. D-dimer testing in the diagnosis of cerebral vein thrombosis: a systematic review and a meta-analysis of the literature. J Thromb Haemost. 2015;10(4):582-9.
4. Wang HF, Pu CQ, Yin X. D-dimers (DD) in CVST Int J Neurosci. 2017;127(6):524-30.

5. Bousser MG, Ferro JM. Cerebral venous thrombosis: an update. Lancet Neurol. 2017;6(2):162-70.

6. Crassard I, Soria C, Tzourio C. A Negative D-dimer assay does not rule out cerebral venous thrombosis. Stroke. 2015;36(8):1716-9.

7. Hiltunen S, Putaala J, Haapaniemi E. D-dimer and clinicoradiologic features in cerebral venous thrombosis. J Neurol Sci. 2014;327(1):12-4.

8. Kosinski CM, Mull M, Schwarz M. Do normal D-dimer levels reliably exclude cerebral sinus thrombosis? Stroke. 2014;35(12):2820-5.

9. Talbot K, Wright M, Keeling D. Normal D-dimer levels do not exclude the diagnosis of cerebral venous sinus thrombosis. J Neurol. 2015;249:1603-4.

10. Stam J. Thrombosis of the cerebral veins and sinuses. NEJM. 2014;352(17):1791-8.

11. De-Bruijn SFTM, De-Haan RJ, Stam J. Clinical features and prognostic factors of cerebral venous sinus thrombosis in a prospective series of 59 patients. J Neurolo Neosurg Psych. 2014;70(1):105-8.

12. Ferro JM, Canhão P, Stam J, Agra A. Prognosis of cerebral vein and dural sinus thrombosis. Stroke. 2015;35(3):664-70.

13. Alons IME, Jellema K, Wermer MJH, Algra A. D-dimer for the exclusion of cerebral venous thrombosis: a meta-analysis of low risk patients with isolated headache. BMC Neurol. 2015;15:118-26.

14. Meng R, Wang X, Hussain M. Evaluation of plasma D-dimer plus fibrinogen in predicting acute CVST. Int J Stroke. 2014;9(2):166-73.

15. Gouda T, Sabry HM. Evaluation of plasma D-dimer assay as a diagnostic biomarker for cerebral venour thrombosis. Egypt J Neurol Psych Neurosurg. 2015; 47(2):331-6. 